\title{
When creativity is the solution: how to transform Makkah into a creative city
}

\author{
S. A. Alamoudy \\ School of Art and Media, University of Salford, UK
}

\begin{abstract}
This paper aims to explore ways in which the theoretical concept of the creative city can be usefully and practically employed in the development of the urban services and global identity of Makkah, Saudi Arabia. The researcher will introduce the previous studies on creative cities and draw the most prominent active theories to find out the best model to suit Makkah as a pilgrimage city, despite it being located in the Middle East where no research on creative cities has been conducted. The aim is to design a model for Makkah inspired by the experiences of successful creative cities, which will be a key solution to the problems that the city faces - problems largely caused by the growing number of pilgrims every year from all around the world. The study will be summarised into four sections as listed below, based on the following questions: What are the key fundamentals that can be distinguished to decide whether a city is successfully presented as a creative city? What are the strategies used and how are they implemented in case studies of creative cities around the world?

Keywords: creative city, city imaging, second tier city, Makkah.
\end{abstract}

\section{Introduction}

Since 1988 (Camilleri [1]), major cities have shown a growing interest in creating an ideal atmosphere for innovation and creativity, which has given rise to the concept of creative cities that are born primarily from mixing cultural and economic policy at the level of strategic planning (O’Connor [2]). Urban planning attempts to formulate new characteristics that combine the factors that a successful city should have, which include: good conditions for the residents by providing them with job opportunities and leisure facilities, promoting of culture, and response to the recent challenges of the global competitive market in the 
context of sustainability and environmental protection (Vlachopoulou and Deffner [3]).

In addition, it is arguable that the lifeblood of cities has always been creativity (Landry and Bianchini [4]). For instance, cities face massive challenges such as economic, infrastructural, social and environmental problems (Suciu [5]) and creativity in these cities will allow creative people to find solutions to the problems that cities face all the time (Costa et al. [6]). Creative cities make an effort to offer motivation, diversity and prosperity to their citizens (Kornbluh [7]).

In his report 'Cultural Industries and the Creative City Fever in Germany', Klaus Kunzmann [8] identifies seven reasons why creative cities have become favourable in (German) post-industrial society. Also in his report 'Creative Cities: What Are They For, How Do They Work, and How Do We Build Them?', Meric Gertler [9] illustrates the benefits of the development of creative cities in Canada.

Table 1: The theories of development of creative cities in Germany and Canada (source: $[8,9]$ ).

\begin{tabular}{|c|c|}
\hline Kunzmann, 2011 & Gertler, 2004 \\
\hline $\begin{array}{l}\text { 1. The positive and open concept of } \\
\text { creativity. } \\
\text { 2. The widely communicated } \\
\text { message. } \\
\text { 3. Structural change, the search for } \\
\text { new economic potentials, the } \\
\text { discovery of the creative } \\
\text { economy. } \\
\text { 4. The return of culture to the } \\
\text { political agenda, driven by } \\
\text { growing urban competition, the } \\
\text { justification and success of } \\
\text { cultural flagships and events, and } \\
\text { the re-design of the physical } \\
\text { urban fabric. } \\
\text { 5. Demographic change, re- } \\
\text { urbanization, urban renaissance } \\
\text { and the emerging cosmopolitan } \\
\text { knowledge society. } \\
\text { 6. The appeal of the creative city } \\
\text { concept to urban marketing and } \\
\text { tourism managers, and to media } \\
\text { searching for success stories. } \\
\text { 7. The opportunity to bridge urban } \\
\text { policies, and the revival of } \\
\text { strategic planning in urban } \\
\text { development. }\end{array}$ & $\begin{array}{l}\text { 1. They play an ever more } \\
\text { important role in enhancing the } \\
\text { dynamism, resilience, and } \\
\text { overall competitiveness of the } \\
\text { economy. } \\
\text { 2. They have the potential to } \\
\text { enhance quality of life and } \\
\text { opportunity for a broad cross- } \\
\text { section of Canadians. }\end{array}$ \\
\hline
\end{tabular}




\section{The case of Makkah}

Makkah has the character and image of a religious city and is a second tier city for tourism. Hodos defines second tier cities as constituting a type characterized by distinct patterns of global integration. He notes that they contain, "Globally active firms in non-financial industries; a common migration pattern; a tradition of innovation in political ideologies and professional/expert cultures; a common historical trajectory due largely to transportation projects that integrate the city more deeply into global flows; and the growth over time of a second-city identity" (Hodos [10]). The urbanization of Makkah not only competes with second tier cities but also strongly competes with global cities in terms of its economy and quality of construction. The government of Saudi Arabia continually spends around \$11 billion on developing and expanding the Holy Places (Kalesar [11]). Makkah has the capacity to cater for approximately three million Muslims from around the world, who will travel to the holy city to perform Hajj or Umrah. This annual arrival of pilgrims, all of whom require accommodation throughout their stay, has turned the real estate in Makkah into some of the most valuable in the world. The Middle East Economic Digest (MEED) published that the cost in Makkah has seen "land prices range from SR $100,000(\$ 27,000)$ a square meter to SR 300,000 $(\$ 80,000)$ a square metre. Over the next five years, analysts estimate that land prices in Makkah and Medina will double. Foreign pilgrims can pay as much as SR $200,000(\$ 53,000)$ for a room covering the last 10 days of Ramadan (these figures refer to Saudi Rials, the Saudi Arabian currency). However, most pilgrims follow the spirit of Hajj by sleeping several to a room and on a low budget” (Irish [12]). Pilgrims come together in Makkah as part of religious tourism, speaking hundreds of different languages in a country they have probably never visited before. This often leads to confusion, especially as pilgrims are required to move from one location to another, due to the sheer volume of people. This research will try to take advantage of the positive and open concept of creativity as applied to Makkah, and also, the appeal of the creative city concept to develop strategy planning.

\section{The concept of the creative cities}

Several previous studies that tackled the issue of the creative city tried to draw the character of the creative city. The pioneer of the creative city idea was the urbanist Jane Jacobs in her 1961 book The Death and Life of Great American Cities (see also: Coletta [13]; Bradford [14]; Sasaki [15]; Brown [16]; Flew [17]). Jacobs explained how cities attract talented people from various backgrounds by such concepts as 'open systems', which motivate their creativity (Acs and Megyesi [18]). Jacobs also recommended that, to stimulate innovation and build new urban expertise, a diversity of activities should be facilitated (Markusen and Schrock [19]).

Nevertheless, the term "creative city” was coined by Charles Landry [4, 20, 21] (see also, for example, [13, 15, 22-27]). However, there has been considerable debate about the concept of a creative city (see, for example, $[4,6$, 
14, 20, 22-27]. Indeed, the conceptual aspect of a creative city is not easy to identify and it is equally difficult to cover all the various applications and practices that are subjacent to it.

The expression of the concept of a creative city seems to be elusive (Coletta [13]) because it reflects a set of distinct ideologies with specific applications of creativity in urban physical and economic development (Simeti [28]). However, the concept becomes much clearer when its components are examined individually. It consists of three major contributors:

- The concepts of which have been clarified in Landry's works - Planning the Creative City, which was discussed in The Creative City: a Toolkit for Urban Innovators by Charles Landry (2000).

- Growing the creative economy (or industries), examined in The Creative Economy: How People Make Money From Ideas by John Howkins (2001).

- Attracting and retaining the Creative Class, which is examined in The Rise of the Creative Class by Richard Florida (2002).

The researcher finds that Landry's theory of the creative city is useful and suitable for Makkah as a religious city. Landry inspires me with his full method of planning and idea of a range of characteristics that is significant to positive development strategies, including an approach based both on planned order, and the urban vitality arising from unplanned, slightly chaotic development. Also, Landry's theory is important in terms of the ability to find new solutions for quotidian problems and involve everyone in developing the city.

\section{Experiences of successful creative cities around the world}

The researcher has highlighted several different "creative city” frameworks that currently inform new visions and creativities. Cities worldwide face significant competition to be attractive for business, talent and tourists. For my studies it is a challenge to select the best framework and practise from over 60 cities that name themselves "creative city" (UNCTAD [30]). I have found out that UNESCO's Creative cities network is a worthy way to select the appropriate examples of successful creative cities that can be a model I follow for my case study. Notably, the aim of this network is to offer a global platform for cities around the world to share their practices and generate new opportunities for themselves and others (Cohendet et al. [31]).

However, what is creative and what is not? Is the right example a template that any city could practice? Indeed, in his article, Andy Pratt argues what is deemed as creative is so context specific that what may be creative in one place or time may not be creative in another context. The creative city is clearly not a 'solve-all' for every urban problem. This needs to be stated clearly. However, there are many instrumental uses to which creative city polices can be put; and critically, there are a number of intrinsic uses as well (Pratt [32]). 
Table 2: Summary of the creative city theories for the three major contributors: Landry, Florida and Howkins (source: [20, 23, 26, 29]).

\begin{tabular}{|c|c|c|c|}
\hline View & Landry & Florida & Howkins \\
\hline $\begin{array}{l}\text { What is } \\
\text { the } \\
\text { creative } \\
\text { city }\end{array}$ & $\begin{array}{l}\text { Creative cities are those } \\
\text { ones able to find new } \\
\text { solutions for quotidian } \\
\text { problems. }\end{array}$ & $\begin{array}{l}\text { The power of the people } \\
\text { (creative people) and the } \\
\text { power of the place (creative } \\
\text { economy). }\end{array}$ & $\begin{array}{l}\text { The creative and } \\
\text { cultural economy } \\
\text { includes: advertising, } \\
\text { architecture, arts, craft, } \\
\text { design, fashion, film, } \\
\text { music, performing arts } \\
\text { (theatre, opera, dance, } \\
\text { ballet), publishing, } \\
\text { research and } \\
\text { development, software, } \\
\text { toys and games, } \\
\text { Television / Radio, } \\
\text { video games. }\end{array}$ \\
\hline $\begin{array}{l}\text { Who } \\
\text { makes the } \\
\text { creative } \\
\text { city }\end{array}$ & $\begin{array}{l}\text { 1. Political and public } \\
\text { framework } \\
\text { 2. Distinctiveness, } \\
\text { diversity, vitality and } \\
\text { expression } \\
\text { 3. Openness, trust, } \\
\text { tolerance and accessibility } \\
\text { 4. Entrepreneurship, } \\
\text { exploration and } \\
\text { innovation } \\
\text { 5. Strategic leadership, } \\
\text { agility and vision } \\
\text { 6. Talent and learning } \\
\text { landscape } \\
\text { 7. Communication, } \\
\text { connectivity and } \\
\text { networking } \\
\text { 8. The place and place- } \\
\text { making } \\
\text { 9. Liveability and well- } \\
\text { being } \\
\text { 10. Professionalism and } \\
\text { effectiveness }\end{array}$ & $\begin{array}{l}\text { 1. The creative class } \\
\text { share of the workforce } \\
\text { 2. Innovation, measured } \\
\text { as patents per capita. } \\
\text { 3. High-tech industry, } \\
\text { using the Milken } \\
\text { Institute's widely } \\
\text { accepted Tech Pole } \\
\text { Index. } \\
\text { 4. Diversity, measured by } \\
\text { the Gay index, a } \\
\text { reasonable proxy for an } \\
\text { area's openness to } \\
\text { different people and } \\
\text { ideas }\end{array}$ & $\begin{array}{l}\text { 1. Creative people } \\
\text { 2. The job of a thinker } \\
\text { 3. The creative } \\
\text { entrepreneur } \\
\text { 4. The post- } \\
\text { employment job } \\
\text { 5. The just-in-time } \\
\text { person } \\
\text { 6. The temporary } \\
\text { company } \\
\text { 7. The network office } \\
\text { and the business cluster } \\
\text { 8. Teamwork } \\
\text { 9. Finance } \\
\text { 10. Deals and hits }\end{array}$ \\
\hline $\begin{array}{l}\text { How to } \\
\text { become a } \\
\text { creative } \\
\text { city }\end{array}$ & $\begin{array}{l}\text { 1. Preparation and } \\
\text { planning } \\
\text { 2. Assessment of } \\
\text { potential obstacles } \\
\text { 3. Measuring success } \\
\text { and failure } \\
\text { 4. Execution } \\
\text { 5. Communicating, } \\
\text { disseminating and } \\
\text { reflecting }\end{array}$ & $\begin{array}{l}\text { Attracting and Retaining } \\
\text { the Creative Class. } \\
\text { 3Ts: Talent, Technology } \\
\text { and Tolerance }\end{array}$ & \\
\hline
\end{tabular}


In theory they are many examples of a creative city but, in practise few of them can be presented as creative in terms of success not just in art; also some cities are already creative yet there are no references about their experience.

In addition, to making my selective cities that much richer in diverse views, I have chosen second tier cities (STCs) from Canada, Japan, the UK, Spain and Australia; this is because my case study Makkah is an STC, and can be categorized as such. Ann Markusen, Yong-Sook Lee and Sean DiGiovanna, defined STCs as, spatially distinct areas of economic activity where a specialized set of trade oriented industries takes root and flourishes, establishing employment and population growth trajectories that are the envy of many other places (Markusen et al. [33]).

The distinctiveness and specialization are the key attributes of these cities. As non-global cities, they lack the homogenization and standardization of Paris, Berlin, London and Sydney. The differences are part of their definitions, their richness, diversity and culture - something that is seen less and less of today. The major challenge is searching for the sources of the cities as they are written and published by the city council such as websites and reports. Indeed, that will affect the neutrality of describing cities and looking for the success of their job. Not only that but also, they use these materials for marketing the city. I have chosen to present each city by the standard points including the city overview, the theory of creative city, the use, the aims and vision and the challenges.

\section{The creative city model}

From the previous examples of models of creative city practices, we can find out that there are common elements contributing to the conversion of those cities into creative cities. Landry says "Successful cities seemed to have some things in common - visionary individuals, creative organization and a political cultural sharing a clarity of purpose" Landry [21]. Furthermore, some model cities fighting for their identities compete with other cities in the country or in the region. Vancouver tries to put itself in the top position in Canadian cities as a British Columbian city; Glasgow also attempts to win the competition as Scotland's city against the rest of the UK cities and Barcelona as the capital of Catalonia. Consequently, business, tourism, solving problems and sustainability motivated those cities to be creative cities.

I have designed a model for creative city 'CREATIVE', which includes Concept, Recourses, Events, Attractive, Theory, Involved, Vision and Eagerness. These elements were inspired from the five creative cities I studied. Almost all the following elements could produce a creative city at any place. My model of a creative city, however, is not limited to just western culture but can apply to any culture. I have aimed to make the model open, clear and easy to use. Moreover, Table 3 shows how I have linked each element with the lettering of the word 'CREATIVE'. 
Table 3: The creative city model elements (source: the author).

\begin{tabular}{|c|c|c|}
\hline Letter & Key elements & Evidence \\
\hline $\mathrm{C}$ & Concept & $\begin{array}{l}\text { The creative city must have a concept that motivates the City } \\
\text { Council and citizens, for example: } \\
\text { - Creative industry: Yokohama aims to be the centre for video } \\
\text { content in Asia and Knowledge city '22@Barcelona’ } \\
\text { - Cultural: Glasgow and Vancouver. }\end{array}$ \\
\hline $\mathrm{R}$ & Resources & $\begin{array}{l}\text { Creative cities use their resources to create their image such as: } \\
\text { - } \quad \text { History and Heritage: Glasgow } \\
\text { Location: Vancouver, Yokohama, Barcelona and Sydney. }\end{array}$ \\
\hline $\mathrm{E}$ & Events & $\begin{array}{l}\text { - Sport: } 2010 \text { Vancouver Olympic and Paralympic Winter } \\
\text { Games, } 1992 \text { Barcelona Olympic Games, } 2000 \text { Sydney } \\
\text { Olympic Games and } 2014 \text { Glasgow Commonwealth Games. } \\
\text { - Cultural: Glasgow the European Capital of Culture and } \\
\text { 2002 Barcelona the Year of Gaudi. } \\
\text { - Conference: Barcelona, Smart City Expo World Congress } \\
2013 \text { and PACIFICO Yokohama. }\end{array}$ \\
\hline A & $\begin{array}{c}\text { Attractivenes } \\
\text { s }\end{array}$ & $\begin{array}{l}\text { - } \quad \text { Tourism industry: Vancouver, Yokohama, Glasgow, } \\
\text { Barcelona Creative Tourism agenda and Sydney. } \\
\text { - Landmark architecture: Sydney (Opera House) and } \\
\text { Barcelona (the Church of La Sagrada Família) }\end{array}$ \\
\hline $\mathrm{T}$ & Theory & $\begin{array}{l}\text { Most cities correspond implicitly with the pioneers of creative city } \\
\text { theory like Landry and Florida. However, the example cities did not } \\
\text { stand by the idea of creative city theories literally, they responded } \\
\text { consistently with their cultural content: } \\
\text { - Vancouver, the Canadian urban policy theorists. } \\
\text { - Yokohama, Landry, Sasaki } \\
\text { - Glasgow, Landry } \\
\text { - Barcelona and Sydney: Landry, Florida }\end{array}$ \\
\hline I & Involvement & $\begin{array}{l}\text { The creative city authority should plan the city with their } \\
\text { people including 3Cs:Citizen, Creative people and } \\
\text { - Communities } \\
\text { - Vancouver, Creative City Task Force } \\
\text { - } \quad \text { Yokohama, a study group } \\
\text { - Sydney, Australia's best minds }\end{array}$ \\
\hline $\mathrm{V}$ & Vision & $\begin{array}{l}\text { Using 2S: Solve the problems and Sustainability } \\
\text { Vancouver, ten years (2008-2018) cultural plan, Yokohama, } \\
\text { 'creative core', Understanding Glasgow', Barcelona, 'Barcelona } \\
\text { 2000’ and Sydney, Sydney 2030 }\end{array}$ \\
\hline $\mathrm{E}$ & Enthusiasm & $\begin{array}{cl}\text { From the government } \\
\text { - } & \text { Financially } \\
\text { - } & \text { Communicational } \\
\text { - } & \text { Supporting }\end{array}$ \\
\hline
\end{tabular}




\section{Conclusion}

In order to transform Makkah into a creative city in theory and practice, the researcher is going to apply this model 'CREATIVE' which has been inspired by five of the most creative cities around the world. The research method will be qualitative interviews with a group of decision-makers in various government institutions and some with the private sector (fifteen interviews) that include:

- National Governor of Makkah.

- City Council of Makkah.

- Academics working in the research centre of Oum Alqura University in Makkah.

- The Commission of the Development Makkah and the Holy Sites.

- General Presidency of Two Holy Mosques.

- Makkah Techno Valley Company.

- Ministry of Pilgrimage.

- Muttawifs (Pilgrim’s Guides).

- Binladin Construction Company.

\section{References}

[1] Camilleri, N., The Creative City: Reality or Rhetoric?: A critique of the recent work of Charles Landry and COMEDIA (p. 104). Berlin: Lap Lambert Academic Publishing, 2010.

[2] O’Connor, J., 'Popular Culture, Cultural Intermediaries and Urban Regeneration. In T. H. and P. Hubbard (Ed.), The Entrepreneurial City. New York: Wiley, 1998.

[3] Vlachopoulou, C., \& Deffner, A., Creative city: A new challenge of strategic urban planning? ERSA conference papers (pp. 1-14). European Regional Science Association, 2011.

[4] Landry, C., \& Bianchini, F., The Creative City. London: Demos, 1995.

[5] Suciu, M., Creative economy and creative cities. The journal of the Romanian Reginnal Science Association, 3(1), 82-91, 2009.

[6] Costa, P., Magalhães, M., Vasconcelos, B., \& Sugahara, G., On "creative cities” governance models: a comparative approach. The Service Industries Journal, 28(3), 393-413, 2008.

[7] Kornbluh, A. T., Cities of the Future/the Future of Cities. Journal of Urban History, 29(4), 483-493, 2003.

[8] Kunzmann, K. R., Cultural Industries and the Creative City Fever in Germany. Seven (pp. 1-23), 2011.

[9] Gertler, M., Creative Cities: What Are They For, How Do They Work, and How Do We Build Them? Networks. Ottawa, 2004.

[10] Hodos, J., Globalization and the Concept of the Second City. City Community, 6(4), 315-333, 2007. 
[11] Kalesar, M. I., Developing Arab-Islamic Tourism in the Middle East: An Economic Benefit or A Cultural Seclusion? International Politics, 3(V), 2010.

[12] Irish, J., Progress for pilgrims. MEED: Middle East Economic Digest, 51(8), 43-48, 2007.

[13] Coletta, C., Fostering the Creative City. CEOs for Cities http://www. ceosforcities.com 2008.

[14] Bradford, N, Creative Cities Structured Policy Dialogue Backgrounder. Networks (p. 16). Attawa, 2004.

[15] Sasaki, M, Urban regeneration through cultural creativity and social inclusion: Rethinking creative city theory through a Japanese case study. Cities. Elsevier Ltd, 2010.

[16] Brown, M. G, The Owl, the City and the Creative Class. Planning Theory \& Practice, 11(1), 117-127, 2010.

[17] Flew, T, Toward a Cultural Economic Geography of Creative Industries and Urban Development: Introduction to the Special Issue on Creative Industries and Urban Development. The Information Society, 26(2), 8591, 2010.

[18] Acs, Z., \& Megyesi, M. I., Creativity and industrial cities: A case study of Baltimore. Entrepreneurship and Regional Development, 24, 1-29, 2009.

[19] Markusen, A., \& Schrock, G., The distinctive city: Divergent patterns in growth, hierarchy and specialisation. Urban Studies, 43(8), 1301-1323, 2006.

[20] Landry, C., The Art of City-Making Building. London, Earthscan, 2007.

[21] Landry, C., The Creative City: A Toolkit for Urban Innovators, (2nd edn), Earthscan, 2008.

[22] Chatterton, P.,Will the real Creative City please stand up? City, 4(3), 390397, 2000.

[23] Florida, R., The Rise of the Creative Class. New York: Basic Books, 2002.

[24] Grundy, J., \& Boudreau, J. A., “ Living with culture “: creative citizenship practices in Toronto. Citizenship Studies, 12(4), 347-363, 2008.

[25] Hansen, A. L., Andersen, H. T., \& Clark, E., Creative Copenhagen: Globalization, Urban Governance and Social Change. European Planning Studies, 9(7), 851-869, 2001.

[26] Howkins, J., The creative economy: how people make money from ideas (p. 288). London: Penguin, 2001.

[27] Peck, J., Struggling with the Creative Class. International Journal of Urban and Regional Research, 29(December), 3-5, 2005.

[28] Simeti, A. M., The "Creative City": Moving from Ideas to Planning Practice. Urban Studies. Massachusetts Institute of Technology, 2006.

[29] Florida, R., Cities and the Creative Class. New York: Routledge, 2005.

[30] UNCTAD., The Creative Economy Report. Creative Economy, A Feasible Development Option. Geneva-New York, 2010.

[31] Cohendet, P., Grandadam, D., \& Simon, L., Rethinking urban creativity: Lessons from Barcelona and Montreal. City, Culture and Society, 2(3), 151-158, 2011. 
1258 The Sustainable City VIII, Vol. 2

[32] Pratt, A. C., Creative cities: Tensions within and between social, cultural and economic development. City, Culture and Society, 1(1), 13-20, 2010.

[33] Markusen, A. R., Lee, Y. S., \& DiGiovanna, S., Second Tier Cities: Rapid Growth Beyond the Metropolis. University of Minnesota Press, 1999. 